\title{
GPA Comparison of Students Admission in SNMPTN and SBMPTN in Department of Physics Education FKIP Unsyiah
}

\author{
Afra Mulya Alamsyah ${ }^{1}$, Susanna ${ }^{2}$, Evendi ${ }^{3}$ \\ Syiah Kuala University, Indonesia ${ }^{1,2,3}$ \\ afra.mulya@mhs.unsyiah.ac.id ${ }^{1}$, susanna@unsyiah.ac.id ${ }^{2}$,evendi@unsyiah.ac.id ${ }^{3}$

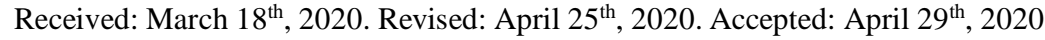

\begin{abstract}
Keywords :
GPA; Students Admission;

ABSTRACT

SNMPTN; SBMPTN

The comparative research with a quantitative approach aims to find out the comparison of the GPA of student admission the SNMPTN and SBMPTN entry points at the Department of Physics Education FKIP Unsyiah. The sample in this study were students of Physics Education 2017-2018 who admission form the SNMPTN 47 students and the SBMPTN 57 students. The collection of research data through the documentation method of admission and transcripts of students grades at the Department of Physics Education FKIP Unsyiah. Analysis and processing data using comparative analysis for two different samples (independent) with using the two samples $t$-tests. The result of $t_{\text {test }}\left(t_{0}\right)=0,71$ and $t_{\text {table }}\left(t_{\alpha}\right)=1,980$. The conclusion in the study, there is no difference in the GPA of students who pass through the SNMPTN and SBMPTN entrance lines at the Department of Physics Education FKIP Unsyiah for the 2017-2018 class.
\end{abstract}

\section{INTRODUCTION}

University is a further education unit for students who have graduated from high school or equivalent to continue their education. It is not an easy matter to get into the desired University. Regulation of the Minister of Research, Technology, and Higher Education of the Republic Indonesia Number 90 of 2017 concerning the acceptance of new students of the program undergraduate at University can be implemented through; (1) students Admission in The National Selection to Enter The State Universities (SNMPTN) is carried out based on the results of prospective students' academic achievements, (2) the Joint Selection Entrance State University (SBMPTN) is carried out based on the results of written examinations in printed form and using computers and taking skill tests for prospective students who choose the sports and arts study program, and (3) state Universities can carry out independent selection which is regulated and determined by each State University.

SNMPTN is one of the selection paths for new student admissions at State Universities throughout Indonesia. The SNMPTN entry point is implemented nationally, where schools wishing to enroll highachieving students to attend SNMPTN must have a National School Number (NPSN) and fill in student data in the School and Student Database (PDSS) completely and correctly. The purpose of SNMPTN are, (1) to provide opportunities for high school/vocational/MA students at home and abroad (School of 
the Republic Indonesia) who have superior achievements to pursue tertiary education at State Universities; and (2) provides an opportunity for State Universities to get prospective new students who have high academic achievements [1].

Unlike the SNMPTN which requires students to excel in school, the SBMPTN can be attended by all students who are less fortunate to attend SNMPTN. SBMPTN requires prospective students to take the Print-Based Writing Examination or Computer-Based Writing Examination and take a skills test for those who choose the art and sports study program. The material being tested is, Academic Potential Test (APT) and General Basic Ability Test (GBAT). The SBMPTN is conducted simultaneously throughout Indonesia with the aim of: (1) selecting prospective students who are predicted to be able to complete studies in tertiary institutions well and on time based on the results of the UTBC or UTBK and other criteria determined jointly by State Universities, (2) providing opportunities for prospective students to choose more than one State Universities across regions, and (3) obtain prospective students who are predicted to be able to complete their studies at destination State Universities based on academic grades only or academic grades and other student achievements [2].

Students who have graduated from tertiary institutions through the three selection paths receive the same treatment process and implementation of learning. These students will be placed in the same classroom and get the same assessment based on the results of the quiz, Midterm Exam, and Final Exam, as well as practical test scores for courses that require practice. The success of the learning process for each student can be seen from the Achievement Index or the Grade Point Average (GPA) obtained at the end of the semester. A study states that there are differences in the basic physics learning achievements of the Department of Physics FMIPA UNM 2014 which were received through the SNMPTN, SBMPTN, and independent pathways. Student achievement received through the SBMPTN pathway has a higher average with a very satisfying predicate, while those who graduate from the SNMPTN pathway have lower grades with a satisfying predicate [3]. There are significant differences in academic achievement and length of study of students majoring in PMIPA FKIP Tanjungpura University, where academic achievement and length of study of students on the SNMPTN pathway are superior and better than the two other pathways (SBMPTN and Mandiri) [4]. Learning achievement is a measure of student success in learning subject matter in the form of grades obtained based on tests/examinations. Achievement in learning is determined by two main factors, namely internal factors and external factors. Syah said that internal factors (factors from within students), namely physical and spiritual conditions of students, while external factors (factors from outside students), namely environmental conditions around students [5]. Learning achievement will increase along with supporting learning factors. Some internal factors, namely, intelligence, motivation to learn, interests and talents. In addition to these internal factors, there are also several external factors that influence learning, including family, learning environment, facilities and infrastructure used.

Students who have graduated through the SNMPTN course are only those who have fulfilled certain requirements. One of the requirements is having academic achievement in school (ranked in class, more importantly in rank I, II, and III). In addition, students who register on the SNMPTN path must also have other achievement certificates, both in the academic and non-academic fields. Students who pass through the SBMPTN entry path are students who do not meet the criteria to take part in the SNMPTN, even SBMPTN can be followed by students who have graduated from school in the last 3 years. As stated in the Regulation of the Minister of Research, Technology and Higher Education Number 90 of 2017 concerning the acceptance of new undergraduate students at tertiary institutions states that the requirements for participants to take part in the SNMPTN, namely: (1) prospective participants are in the last class of secondary education who will graduate in the current year; (2) prospective participants have consistently good academic performance; (3) prospective participants enter the best ranking quota in schools determined based on school accreditation; and (4) prospective participants fulfill other requirements determined by each State Universities. Requirements for participants to take part in the SBMPTN, namely: (1) The participant already has a diploma or certificate of graduation from secondary education; and (2) secondary education graduates of the last three years. 
Seeing the difference in qualifications /requirements, there will certainly be speculation /thinking that students who pass through the SNMPTN will have higher and higher GPA compared to students who pass through the SBMPTN. This thought agrees with Lodang \& Palennari, ideally students from the PMJK pathway should have a superior GPA because they are recruited from among smart students in their home schools [6].

\section{METHOD}

This research was conducted in the physics education department FKIP Unsyiah. The population in this study were students of Physics Education FKIP Unsyiah from 2107-2018 as many as 121 students with a sample of 47 students who passed through SNMPTN and 57 students who passed through SBMPTN. The collection of research data through the documentation method. Analysis dan processing data using comparative analysis for two different samples (independent) with using the two samples t-tests [7].

$$
t_{0}=\frac{\overline{X_{1}}-\overline{X_{2}}}{\sqrt{\frac{\left(\sum X_{1}^{2}-\frac{\left(\sum X_{1}\right)^{2}}{n_{1}}+\sum X_{2}^{2}-\frac{\left(\sum X_{2}\right)^{2}}{n_{2}}\right)}{\left(n_{1}+n_{2}-2\right)}\left(\frac{n_{1}+n_{2}}{n_{1} n_{2}}\right)}}
$$

Information:

$$
\begin{array}{ll}
t_{0} & =\text { statistical test value } \\
\bar{X}_{1} & =\text { average value of variable } 1 \\
\bar{X}_{2} & =\text { average value of variable } 2 \\
\sum X_{1} & =\text { number of variables } 1 \\
\sum X_{2} & =\text { number of variables } 2 \\
\mathrm{n}_{1} & =\text { number of samples in variable } 1 \\
\mathrm{n}_{2} & =\text { number of samples in variable } 2
\end{array}
$$

\section{RESULTS AND DISCUSSIONS}

Based on the data and the results of data processing that has been done above, obtained $t_{0}=0.71$ with a real level of $5 \%=0.05$ and with $\mathrm{db}=102$, obtained $\mathrm{t}_{\alpha}=1.980$. In connection with $\mathrm{t}_{0} \leq \mathrm{t}_{\alpha}(0.71 \leq 1,980)$, $\mathrm{H}_{0}$ was accepted and $\mathrm{H}_{1}$ was rejected, it is meaning that there was no difference in the GPA of students who passed through the SNMPTN and SBMPTN admissions at the Department of Physics Education FKIP Unsyiah. The results of this study are consistent with Claudya, which states that the results of data processing using the ANOVA test shows that there is no difference in the achievements of Physics students FKIP Unsyiah who passed through the SNMPTN, SBMPTN and UMB in 2013-2016 [8]. In line with the study, Utomo also concluded that there was no difference in academic learning achievement between invited students of the SNMPTN track and the SPMB track in 2013 FIK Unesa sports education students [9].

Another study that is similar to the results of the research that has been obtained is the research on FTUNP Informatics Engineering students who showed that there were no significant differences in learning outcomes between regular selection students and Mandiri Selection in the 2014-2017 generation [10]. Other studies that are in line with the results of research conducted are research on Biology FMIPA UNM students stating that there is no difference in academic achievement of students in the PMJK / PMDK pathway and the SPMB pathway with the average GPA of PMJK / PMDK pathway students 
amounted to 2.9582 and the average GPA of SPMB students was 2.9587 [6].

The results obtained differ greatly from the existing assumptions, where the results in this study there are no differences in student achievement SNMPTN and SBMPTN in the Department of Physics Education FKIP Unsyiah. This shows the ability and encouragement of students who graduate through the SNMPTN and SBMPTN pathways are not much different. Learning abilities and encouragement are part of internal factors in learning. As said Slameto that the internal factors in learning are intelligence (ability), interests, talents, motives (encouragement to achieve goals), attention, maturity, and readiness [11]. Based on the similarity in ability and encouragement in learning shows that SBMPTN track students will also be able to compete with SNMPTN track students so that the average GPA is not much different, namely the average GPA of SNMPTN track 3.43 and the average GPA of SBMPTN track 3.38 .

Based on the results of the study, the academic achievement in Higher Education, especially in Physics Education FKIP Unsyiah is not only determined based on the entry point, but also the motivation of students to learn. Students should have high learning motivation as a manifestation and prestige they carry, besides that the indicators in learning motivation are the encouragement and needs in learning, the hopes and ideals of the future, the existence of activities that interesting in learning, and there is an interesting learning environment [6]. Motivation to learn in this case acts as a driving force that drives the desire to re-learn the lessons learned as well as studying the material for further discussion. Another research result states that there is an influence of motivation and family support on the learning achievements of Midwifery University Students at Ubudiyah Indonesia [12].

Syah states that learning of motivation can be divided into two types, namely intrinsic motivation, and extrinsic motivation. Intrinsic motivation is things and circumstances that come from within a person that can encourage him to take action to learn [5]. One part of intrinsic motivation is the feeling of caring for the material and its needs for the material. Extrinsic motivation is things and circumstances that come from outside oneself that can encourage them to do learning activities. Some descriptions of extrinsic motivation are, such as praise and gifts, school rules and regulations, role models of parents, teachers, friends, and so on that can foster a desire to learn.

There was no difference in the GPA obtained in this study due to several factors, such as learning motivation, learning interest, campus environment, family support, and other factors. Corresponds to what was concluded by Likuwahwa et al that the factors that influence GPA on students are factors of interest in learning, campus environment, and family environment. This shows that the Physics Education FKIP Unsyiah students have relatively similar learning factors, so there will be a possibility for students who graduate through the SBMPTN to have a higher GPA compared to students who graduate through the SNMPTN pathway [13].

\section{CONCLUSION AND SUGGESTION}

The conclusion in the study, namely there is no difference in the GPA of students who pass through the SNMPTN and SBMPTN entrance lines at the Department of Physics Education FKIP Unsyiah for the 2017-2018 class. For further research are expected to be researching more about admission in State Universities and learning motivation as well as the economic background of prospective students, thus increasing students GPA. In addition, it can also examine about problems a GPA of Bidikmisi students and Non-Bidikmisi students

\section{ACKNOWLEDGMENTS}

Thanks to all student of Physics Education for the 2017-1028 class who helped me to complete my thesis. Then to my lecture, Mrs. Dra. Susanna, M. Pd and Mr. Dr. Evendi, M. Pd, thank you very much 
on your suggestion and guidance during in. I can't replace what that you give to me, and to the all of operators Department of Physics Education, thanks too all the assistance provide during this.

\section{REFERENCES}

[1] TSI LTMPT. (2019). Informasi Umum SNMPTN 2019. [Online]. Available: http://snmptn.ac.id/informasi.html?1426322267

[2] LTMPT. (2019). SBMPTN 2019. [Online]. Available: https://sbmptn.ltmpt.ac.id/?mid=13.

[3] Usman, U. (2015). Analisis Perbandingan Prestasi Belajar Fisika Dasar Mahasiswa Berdasarkan Jalur Penerimaan Mahasiswa Di Jurusan Fisika Fakultas Matematika Dan Ilmu Pengetahuan Alam Universitas Negeri Makassar. Jurnal Sains dan Pendidikan Fisika, 11(1).

[4] Djudin, T. (2018). Analisis Prestasi Akademik Mahasiswa Lulusan Jurusan Pendidikan MIPA FKIP Untan Ditinjau Dari Jalur Masuk (SNMPTN, SBMPTN, Mandiri) Dan Program Kuliah (S1 Reguler, S-1 Percepatan APK). Jurnal Pendidikan Matematika dan IPA, 9(2): 76-88.

[5] Syah, M. (2006). Psikologi Belajar. Jakarta: PT Raja Grafindo Persada.

[6] Lodang, H., \& Pallennari, M. (2010). Perbandingan Prestasi Akademik Mahasiswa Jurusan Biologi Jalur PMJK/PMDK dengan SPMB. Jurnal Bionature, 11(1): 50-53.

[7] Hasan, I. (2010). Analisis Data Penelitian dengan Statistik. Jakarta: Bumi Aksara.

[8] Claudya, Y., Ngadimin, N., \& Melvina, M. (2017). Perbedaan prestasi belajar mahasiswa berdasarkan jalur seleksi masuk Jurusan Pendidikan Fisika Universitas Syiah Kuala. Jurnal Ilmiah Mahasiswa Pendidikan Fisika, 2(3): 321-325.

[9] Utomo, F. L. (2015). Perbandingan Motivasi Belajar, Prestasi Belajar Akademik Dan NonAkademik Antara Mahasiswa Jalur SNMPTN Undangan Dengan Jalur SPMB (Studi pada mahasiswa Prodi S-1 Penjaskesrek angkatan 2013 FIK UNESA). Jurnal Pendidikan Olahraga dan Kesehatan, 3(2).

[10] Putra, R., \& Edidas, E. (2019). Komparatif Hasil Belajar Mahasiswa Reguler Dengan Mandiri Pendidikan Teknik Informatika FT-UNP. Jurnal Vocational Teknik Elektronika dan Informatika, 7(2): 126-131.

[11] Slameto. (2003). Belajar dan Faktor-faktor yang Mempengaruhinya. Jakarta: PT Rineka Cipta.

[12] Safitri, F., \& Yuniwati, C. (2019). Pengaruh Motivasi dan Dukungan Keluarga terhadap Prestasi Belajar Mahasiswa Tingkat II Prodi D-III Kebidanan Universitas Ubudiyah Indonesia. Journal of Healthcare Technology and Medicine, 2(2): 154-161.

[13] Likumahwa, F. M., Yahya, R., Bakhtiar, A., \& Santoso, H. (2018). Analisis Faktor-Faktor yang Mempengaruhi Indeks Prestasi Mahasiswa dengan Metode Analisis Faktor dan Analisis Diskriminan. IENACO (Industrial Engineering National Conference) 62018. 